\title{
DOYNE REVISITED
}

\author{
MARCELLE JAY, CATHERINE PLANT, KEVIN EVANS, CHERYL Y. GREGORY \\ London
}

\begin{abstract}
SUMMARY
Inherited retinal dystrophies are important causes of blindness in the Western world. Molecular genetic techniques, and the use of large pedigrees exhibiting such conditions, have been instrumental in finding causative disease genes. The genealogy of families with a rare condition known as Doyne's honeycomb retinal degeneration was first described in 1899. Investigating this phenotype is extremely important because of the similarities it shares with age-related macular degeneration, and it may lead us to a gene that is involved in this complex genetic trait. In this paper we review the original genealogy of the families described by Doyne, and explain the methods used to identify the living descendants of these families.
\end{abstract}

In 1899, Robert Walter Doyne ${ }^{1}$ first described an English family with a condition which he called choroiditis, and which was subsequently known as Doyne's honeycomb degeneration of the retina due to a characteristic appearance of the fundus. His first description was brief and stressed the familial nature of the condition; there were four affected sisters, and their father and one of his brothers and the paternal grandmother were also affected. There was a honeycomb appearance of the fundus with white spots affecting almost entirely the macular region of the disc.

Eleven years later, other members of the same family had been seen and it was known that a female cousin was also affected. ${ }^{2}$ The same paper mentioned a young woman aged 20 years unaffected at the time, the daughter of two affected parents who were first cousins. In yet another paper ${ }^{3}$ Doyne had thought of making copies of the pedigree and circulating them among his colleagues as the family was very large and dispersed all over the country. There were two families which he was trying to link together: one near Aylesbury (Buckinghamshire) and the other between Witney and Oxford (Oxfordshire). In his

From: Department of Clinical Ophthalmology, Moorfields Eye Hospital, City Road, London EC1V 2PD, UK.

Correspondence to: Dr M. Jay, 10 Beltane Drive, Wimbledon, London SW19 5UR, UK. final communication ${ }^{4}$ Doyne wrote: 'I am keeping my attention carefully on some of the older cases, and I hope if I live long enough I may be able to bring before the Society some microscopical specimens.'

That honour was given to Treacher Collins ${ }^{5}$ in 1913, who described the histopathology of the posterior part of the eye of a member of the family. Treacher Collins is quoted in a later study ${ }^{6}$ as having been given the eyes by 'the late Mr Doyne'. The original report, which might have led to finding the blocks, cannot be found either at the Institute of Ophthalmology or at the Eye Hospital in Oxford.

In 1937 Tree $^{7}$ was able to examine two families with Doyne's choroiditis, one originating from Eynsham (Oxfordshire) and the other from High Wycombe (Buckinghamshire). Both were descendants of the families originally described by Doyne. A generation later, Pearce ${ }^{8,9}$ was able to trace their descendants by using Doyne's unpublished pedigrees. He examined 296 individuals from six families, of whom 76 were affected. The six pedigrees, labelled $\mathrm{A} 1$ and $\mathrm{A} 2, \mathrm{~B}, \mathrm{C}, \mathrm{D}$ and $\mathrm{E}$, are so large that the paper is folded in concertina fashion to accommodate them. Pedigree B corresponded to the family from Eynsham in the paper by Tree, family E originated from the Vale of Evesham (Worcestershire), while the remaining families originated from High Wycombe.

\section{THE PRESENT STUDY}

In his concluding remarks, Dryja ${ }^{10}$ the 1991 Doyne lecturer, predicted that the gene for Doyne's would be isolated within the next 20 years. As it is an autosomal dominant condition, he said that it should be straightforward for an ophthalmologist to collect blood samples from one or two large families with the condition, and then identify the gene by the linkage or the candidate gene approach. The importance of this is that Doyne's honeycomb degeneration is an excellent model for age-related macular degeneration.

Three years later it was decided to do this, and the 


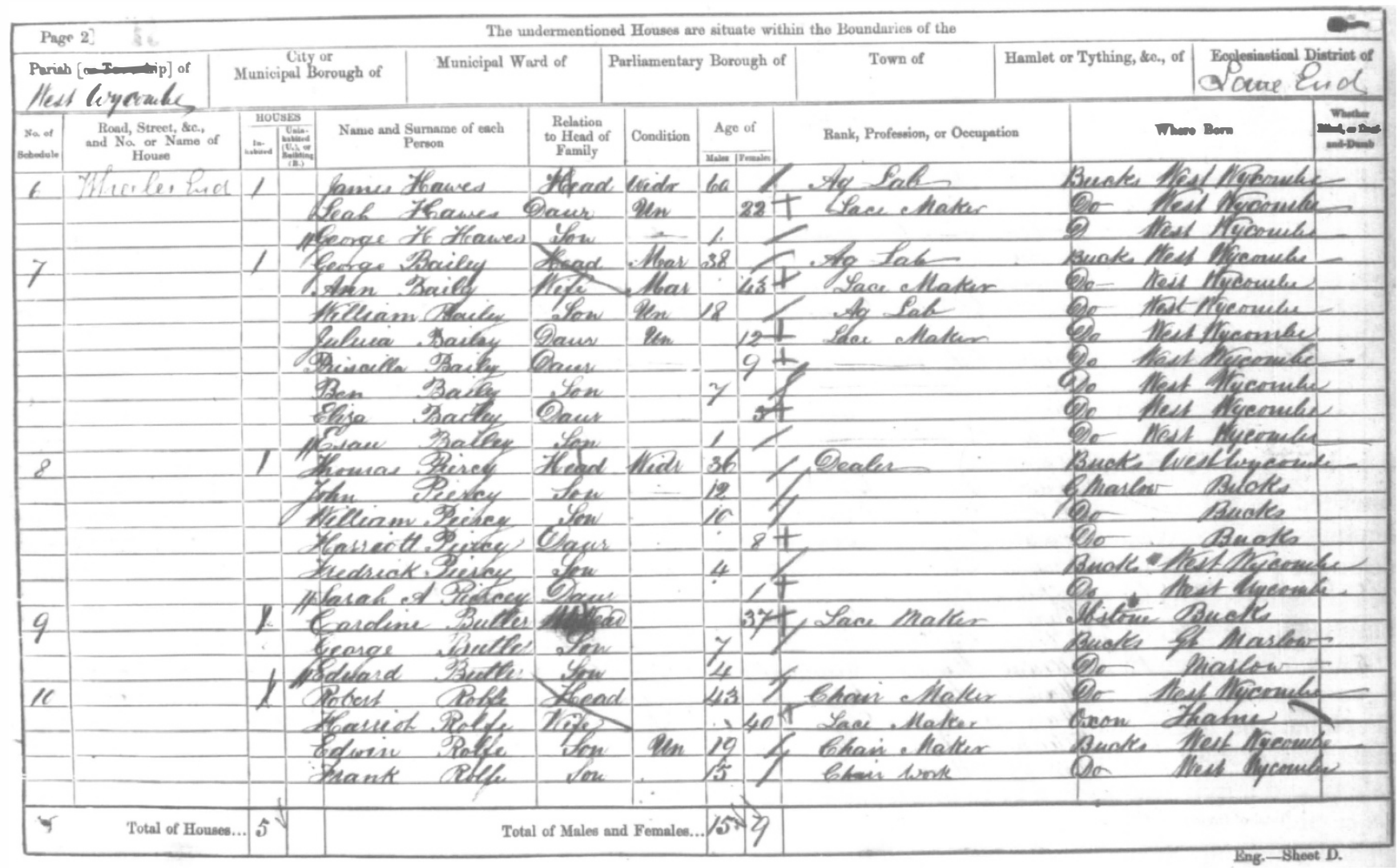

Fig. 1. Entry from the 1861 census (PRO reference RG9 860 f.51 p.2) showing the household of George and Ann Bailey, and their daughter Priscilla aged 9 years. (Crown copyright, reproduced with permission of the Controller of Her Majesty's Stationery Office.)

first task was to choose the families, identify the individuals and collect their blood samples. The obvious families to choose were the High Wycombe families first described by Doyne, and whose pedigrees were subsequently published by Pearce. Unfortunately, the exact whereabouts of the original Doyne pedigrees are not known. All efforts to identify individuals in the Pearce pedigrees were to no avail; the pedigrees were drawn by an artist working for Blackwell's Scientific Publications who worked from 'bits of paper' which he returned to the Churchill Hospital in Oxford. Blood samples had been taken from every individual and sent to a now defunct unit in Oxford. The bottles would have had names and dates of birth, and these names could have been fitted somehow into the pedigrees.

Pearce very kindly sent a list of 17 names (but with no first names and no maiden names) and an approximation of the age in 1968. It was possible to work out from this list, and from the 1968 paper, ${ }^{9}$ which six individuals belonged to pedigrees $\mathrm{B}, \mathrm{C}, \mathrm{D}$ and $\mathrm{E}$, which are the smaller pedigrees. Family B was from Eynsham, and the local telephone directory gave several entries for the surname but only one with the correct initial. The disease has died out in this family, and it became imperative to identify all the names on the large A1 and A2 pedigrees, the families from High Wycombe.
The paper by Tree $^{7}$ has a long appendix with case histories of individuals identified by name, initial of surname and position in the pedigree, which provided an added source of information concerning the family. In particular, there was a Mrs Priscilla $\mathrm{H}$, née $\mathrm{B}$, reputedly aged 47 years in 1904 and therefore born in 1857 in High Wycombe.The name Priscilla is a most unusual one for a child born in Victorian times, and it enabled her to be found on a census entry. The census for England and Wales takes place every 10 years, and returns from 1841-1891 only are on microfilm. The census covered every household from Buckingham Palace to the lowliest dwelling, including hospitals, prisons and workhouses, and it is ordered geographically. An address is therefore mandatory, unless one is prepared to spend a lot of time looking for a single $35 \mathrm{~mm}$ frame among several hundred metres of microfilm.

The return for Wheeler End in West Wycombe in the census of 1861 shows the household of George Bailey and his wife Ann (Fig. 1). Their third child is Priscilla aged 9 years and thus born in 1852 at West Wycombe which, at the time, had a population of 2000. A search of the original parish registers gave George Bailey as the third child of James and Harriet Bailey. This couple had 10 children, including two sets of twins, and this family corresponds to the pedigree A2 of Pearce. 


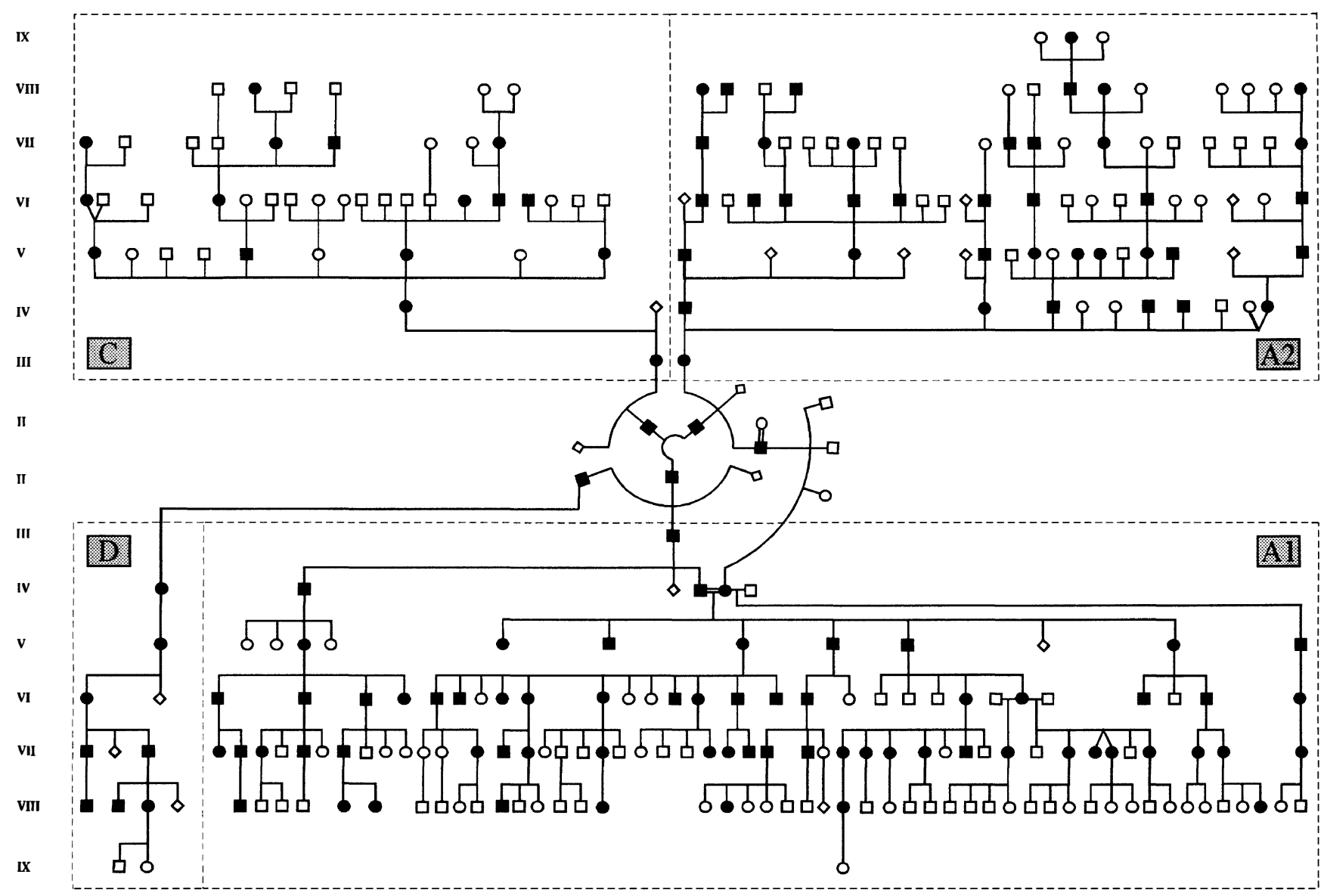

Fig. 2. The current pedigree of the family with Doyne's honeycomb choroiditis as used in linkage.

From the census entry for James and Harriet Bailey, it appeared that Harriet was born in about 1798 in a village by the name of Bledlow, which in 1851 had a population of 1200 . A Harriet Brooks married a James Bailey in 1818 at Bledlow, but marriage entries did not give the name of the father of both parties until 1837. Bledlow is a few miles from West Wycombe and it is also near Aylesbury, where Doyne described it. The family surname of the four sisters described by Doyne was Brooks, daughters of a Henry Brooks who was born in 1806. The Brooks family corresponds to the pedigree $\mathrm{A} 1$ of Pearce.

\section{RESULTS AND DISCUSSION}

The task of finding the descendants would have taken very much longer than it did but for some very welcome publicity from local newspapers and a national evening paper. As a result people wrote in, and a very generous offer of professional help from a firm of genealogists and probate agents was received. An article in a local family history journal aroused keen interest, here and abroad. The presentday version of the Doyne pedigree appears as in Fig. 2 , which is the pedigree in use for DNA linkage. These combined efforts enabled us to conduct a family survey in early September 1994, when 64 members of the family arrived throughout the day, were photographed and had blood samples taken for linkage.

Nine generations of this family are now known, and the family has been traced back to about 1740 (Fig. 3). The first four generations show the different members of the Brooks family of Bledlow who founded the Pearce pedigrees A1, A2, C and D. Common ancestry with the other two pedigrees has not been found although more is known of the origins of these two other families. The so-called

$$
\text { BRDOKS FAMILY }
$$

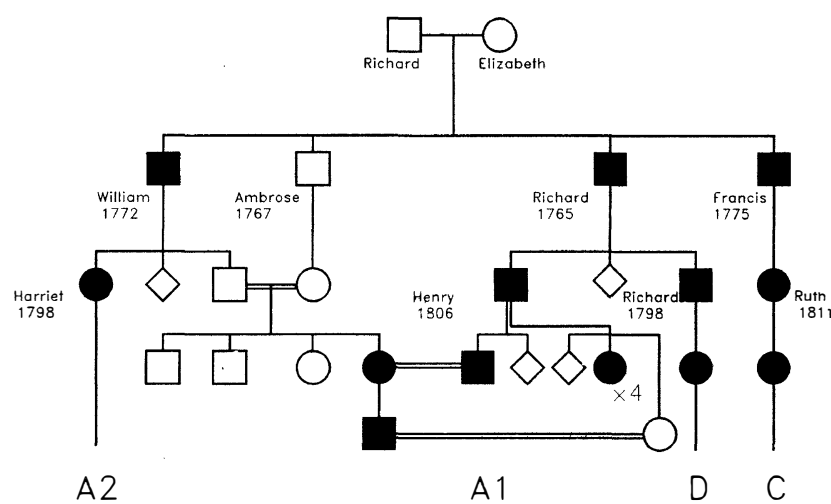

Fig. 3. The founders of the Brooks family of Bledlow. 
'Eynsham' family (Pearce pedigree B) originated in fact from Stanton Harcourt, which is near Oxford and about 25 miles $(40 \mathrm{~km})$ from Bledlow, while pedigree E family came from Weston Subedge, which is to the north-west of Oxford and about 60 miles $(100 \mathrm{~km})$ from Bledlow. It would have taken only one itinerant workman in the early eighteenth century to have travelled from one place to the other on this itinerary; Richard Brooks was a rat-catcher, an occupation much in demand around the country at that time.

We are very much indebted to the expertise and generosity of the firm of G.B. Hooper, without whom the tracing of the descendants would have been beyond our resources, and in particular Nikki Lemos and Philip Mercer who did the searches. We would also like to thank Professor Bron for his encouragement, Dr Pearce for the list of patients from his original study, Mr Nigel Cox and Mr Tony Moore for patients. We are grateful for the support of the British Retinitis Pigmentosa Society, the National Retinitis Pigmentosa Foundation, and Cancer Research Campaign for funding our research.

Key words: Choroiditis, Honeycomb degeneration, Doyne, Retina, Gene.

\section{REFERENCES}

1. Doyne RW. Peculiar condition of choroiditis occurring in several members of the same family. Trans Ophthalmol Soc UK 1899;19:71.

2. Doyne RW. A note on family choroiditis. Trans Ophthalmol Soc UK 1910;30:93-5.

3. Mould GT. Family choroiditis. Trans Ophthalmol Soc UK 1910;30:189-90.

4. Doyne RW. Further notes on family choroiditis. Trans Ophthalmol Soc UK 1910;30:274-6.

5. Collins E Treacher. A pathological report upon a case of Doyne's choroiditis ('honeycomb' or 'family' choroiditis). Ophthalmoscope 1913;11:537-8.

6. Foster J. Two cases of ? Doyne's familial choroiditis. Proc R Soc Med 1932;25:990-1.

7. Tree M. Familial hyaline dystrophy in the fundus oculi or Doyne's family honeycomb 'choroiditis'. Br J Ophthalmol 1937;21:64-91.

8. Pearce WG. Genetic aspects of Doyne's honeycomb degeneration of the retina. Ann Hum Genet 1967; 31:173-87.

9. Pearce WG. Doyne's honeycomb retinal degeneration: clinical and genetic features. Br J Ophthalmol 1968; 52:73-8.

10. Dryja TP. Doyne Lecture. Rhodopsin and autosomal dominant retinitis pigmentosa. Eye 1992;6:1-10. 